\title{
KARAKTER PESERTA DIDIK DAN HUBUNGANNYA DENGAN KETERAMPILAN BERPIKIR KRITIS DALAM PEMBELAJARAN FISIKA SISWA SMP
}

\author{
Muhammad Agus Martawijaya \\ Ahli Pendidikan Fisika \\ Fakultas Matematika dan Ilmu Pengetahuan Alam \\ Universitas Negeri Makassar, Indonesia \\ E-mail: mamwijaya@yahoo.co.id
}

\begin{abstract}
The purpose of this study was to find the link between the characters of students with their critical thinking skills in learning physics at Junior High School at Barrang Lompo Island, South Sulawesi. The research method used was embedded mixed design. The results of the study showed that (1) the characters of the students in learning physics at Barrang Lompo Island were still very low, (2) critical thinking skills of students in learning physics at Barrang Lompo Island were still low, and (3) there was a significant correlation between students' characters with their critical thinking skills in learning physics. The level of critical thinking skills of students determined by the nature of the student honesty reached $76.3 \%$ and their curiosity reached $73.49 \%$. It is concluded that (1) the character and thinking skills of students in learning physics at Barrang Lompo Island are still low, (2) there is a significant correlation between the characters of students with their critical thinking skills.
\end{abstract}

Keywords: student's characters, critical thinking skills, learning physics

\begin{abstract}
ABSTRAK
Tujuan penelitian ini adalah menemukan hubungan antara karakter dan keterampilan berpikir kritis peserta didik dalam pembelajaran fisika SMP di pulau Barrang Lompo, Sulawesi Selatan. Metode penelitian yang digunakan adalah desain campuran. Hasil penelitian menunjukkan bahwa: (1) karakter peserta didik dalam pembelajaran Fisika di pulau Barrang Lompo masih rendah; (2) Keterampilan berpikir kritis peserta didik dalam pembelajaran Fisika di pulau Barrang Lompo masih rendah; dan (3) Ada hubungan yang signifikan antara karakter peserta didik dengan keterampilan berpikir kritis peserta didik dalam pembelajaran fisika. Tingkatan keterampilan berpikir kritis peserta didik dibandingkan dengan kejujuran peserta didik meningkat secara cukup baik dan keingintahuan meningkat secara cukup baik juga. Dengan demikian, dapat disimpulkan bahwa: (1) karakter dan kemampuan berpikir peserta didik dalam pembelajaran fisika di pulau Barrang Lompo masih rendah; (2) Terdapat hubungan yang signifikan antara karakter peserta didik dengan keterampian berpikir kritis.
\end{abstract}

Kata Kunci: karakter peserta didik, keterampilan berpikir kritis, pembelajaran fisika

\section{PENDAHULUAN}

Dalam mencapai tujuan objektif pendidikan di Indonesia, Menteri Pendidikan dan Kebudayaan membuat berbagai jenis usahayang dihubungkan dengan pendidik dan peserta didik. Sementara itu, isu terkait perilaku karakter yang buruk seperti korupsi, konflik horisontal, perbuatan seksual, penggunaan obat-obatan terlarang adalah suatu hal yang menakutkan dan menjadi topik terhangat di berbagai media, seminar, dan berbagai jenis kegiatan nasional. Pengamat sosial menunjukkan bahwa krisisi di Indonesia berasal dari kegagalan lembaga pendidikan dalam pengembangan perilaku berkarakter peserta didik. Pendidik menerapkan 
sebuah paradigma dengan memberikan banyak perhatian dalam memberikan pengetahuan dan mengesampingkan pengembangan karakter dalam proses pembelajaran. Hal lain pada pencapaian peserta didik dalam aspek keterampilan berpikir kritis tidak berpengaruh, termasuk dalam pembelajaran Fisika SMP khususnya peserta didik yang tinggal dalam daerah terpencil, seperti di pulau Barrang Lompo.

Studi pendahuluan menunjukkan bahwa keterampilan berpikir kritis dalam fisika (konsep massa jenis) pada peserta didik SMP di pulau Barrang Lompo yang lokasinya masih berada di dalam kota Makassar, Sulawesi Selatan. Dari 50 peserta didik yang terlibat dalam pembelajaran, hanya 8 orang yang memperoleh skor $5-7$ dari skor 10 , dan 42 orang mempoleh skor antara $0-$ 4. Dengan memperhatikan hasil tersebut, sebuah penelitian menuntut rencana penyelidikan yang digunakan pendidik untuk mengajarkan konsep massa jenis dikombinasikan dengan wawancara lima orang peserta didik. Hal tersebut ditemukan bahwa pendidik mengabaikan pentingnya nilai karakter yang dibutuhkan peserta didik. Dalam pembelajaran fisika dilatihkan kejujuran dalam mengamati dan menghitung. Adanya keteledoran dan ketidakjujuran peserta didik tidak akan memahami dengan baik tentang fenomena fisika (Zubaedi: 2007).

Ilmu Pengetahuan Alam. Fisika adalah bagian Ilmu Pengetahuan Alam yang peranannya sama dengan mata pelajaran lain dalam mengembangkan sikap karakter peserta didik. Pengembangan pendidikan Sains dalam berbagai negara percaya bahwa peranan sains dalam pengemabangan karakter untuk setiap warga negara. Ini merupakan alasan karena produk sains tumbuh dengan sangat cepat, proses tersebut dapat ditransferkan dengan efektif dalam bidang lainnya, dan memuat nilai, sikap, dan moral (Zuchdi, et.al. 2010). Dalam penelitian saat ini, hubungan antara karakter peserta didik dengan kemampuan berpikir kritisnya dalam pembelajaran fisika di pulau Barrang Lompo, Sulawesi Selatan tersebar luas.

Fisika berkaitan dengan cara mencari tahu tentang alam secara sistematis, sehingga Fisika bukan hanya penguasaan kumpulan pengetahuan yang berupa fakta-fakta, konsepkonsep, atau prinsip-prinsip saja tetapi juga merupakan suatu proses penemuan. Melalui mata pelajaran Fisika diharapkan dapat menjadi wahana bagi peserta didik untuk mempelajari diri sendiri dan alam sekitar, serta prospek pengembangan lebih lanjut dalam menerapkannya di dalam kehidupan sehari-hari. Di tingkat SMP/MTs diharapkan ada penekanan pembelajaran Salingtemas (Sains, Lingkungan, Teknologi, dan Masyarakat) yang diarahkan pada pengalaman belajar untuk merancang dan membuat suatu karya melalui penerapan konsep fisika dan kompetensi bekerja ilmiah secara bijaksana.

Dalam hubungan ini, Einstein menekankan bahwa penggunaan metode dalam pengembangan fisika bersiklus di mana diawali dan diakhiri dengan fakta (Poedjiadi, 1987). Hal ini dapat disimpulkan: (1) makna dalam membangun pola pikir; (2) makna dalam menjelaskan; (3) makna dalam memprediksi; (4) makna dalam mengontrol; dan (5) makna dalam memelihara. Tujuan dari sains oleh Carl Sagan ( Koes, 2003) adalah menemukan regulasi dari dari alam dan bagaimana melakukan kegiatannya, dan menjawab masalah dari fenomena alam.

Adler (2009) mengemukakan butir-butir penting yang berkenaan dengan tujuan mata pelajaran IPA adalah peserta didik memperoleh pemahaman tentang: (1) cara kerja ilmu pengetahuan alam, dalam arti metode ilmiah; (2) konsepsi terbaru tentang alam semesta, dalam arti baru bagi peserta didik; (3) hakekat sistem kehidupan, khususnya sistem kehidupan manusia; dan (4) perkembangan pemikiran ilmiah pada masa lalu serta implikasinya pada masa sekarang dan pada masa yang akan datang. Sejalan dengan itu, Sauri (dalam Zubaedi, 2011) mengemukakan bahwa tujuan pendidikan IPA memiliki beberapa komponen, antara lain: (1) hubungan antara IPA dan bidang-bidang lain; (2) peranan IPA di dalam masyarakat; (3) implikasi sosial dan kultur dari IPA; dan (4) hubungan antara IPA, teknologi, dan masyarakat.

Kemampuan Berpikir Kritis adalah aktivitas mental yang dilakukan untuk mengevaluasi kebenaran sebuah pernyataan. Umumnya evaluasi berakhir dengan keputusan untuk menerima, menyangkal, atau meragukan kebenaran pernyataan yang bersangkutan. Rudinow \& Barry (dalam Fisher 2009)) mendefinisikan berpikir kritis sebagai sebuah proses yang menekankan sebuah basis 
kepercayaan-kepercayaan yang logis dan rasional, dan memberikan serangkaian standar dan prosedur untuk menganalisis, menguji dan mengevaluasi.

Kemampuan berpikir kristis dapat berkembang sangat pesat menggunakan pembelajaran berbasis portofolio karena hal ini hampir semua memfasilitasi kemampuan peserta didik dalam mengembangkan pengetahuan yang telah dipahami peserta didik. Kemampuan mempredikdi dari keterbatan informasi, kemampuan untuk menemukan masalah, merumuskan hipotesis, menguji hipotesis dan kemampuan untuk melihat informasi dari berbagai pandangan.

Pengembangan Karakter. Ada beberapa pandangan yang melahirkan gagasan dalam mengembangakan perilaku karakter seseorang, diantaranya: (1) aliran alam dan aliran interaksi (Adi, et al.,2010). Hidayatullah (dalam Asmani, 2011) menyarankan bahwa pengembangan karakter seseorang melalui beberapa fase yaitu: (1) menumbuhkan etika ( usia 5-6 tahun); (2) menumbuhkan rasa tanggung jawab (usia $7-8$ tahun); (3) menumbuhkan rasa peduli (usia 9 10 tahun); (4) menumbuhkan rasa mandiri (usia 11-12 tahun), dan (5) menumbuhkan pentingnya komunikasi (usia 13 ke atas). Fase pengembangan perilaku karakter akan menjadi dasar bagi pendidik dalam menjalankan usaha pengembangan perilaku karakter peserta didik dalam pembelajaran.

Dalam kesempatan ini dikemukakan usaha pengembangan perilaku karakter peserta didik di Indonesia karena karakter dapat mengatur pola piker siswa. Terdapat beberapa strategi yang dapat diselesaikan, salah satunya adalah strategi berbasis pendidikan.

Untuk itu tujuan penelitian ini adalah: (1) untuk mengetahui Sejauhmana prilaku karakter dan keterampilan berpikir kritis peserta didik fisika di pulau Barrang Lompo, Sulawesi Selatan (2) untuk mengetahui hubungan antara prilaku karakter dengan keterampilan berpikir kritis peserta didik dalam pembelajaran fisika

Hipotesis yang dikemukakan adalah terdapatnya hubungan yang signifikan antara prilaku karakter dan berfikir kritis peserta didik dalam pembelajaran fisika.

\section{METODE PENELITIAN}

Metode penelitian digunakan adalah pengembangan desain Embedded Mixed oleh Creswell. J.W \& Plano Clark, V. L. (2007) yang ditunjukkan pada gambar 1 .

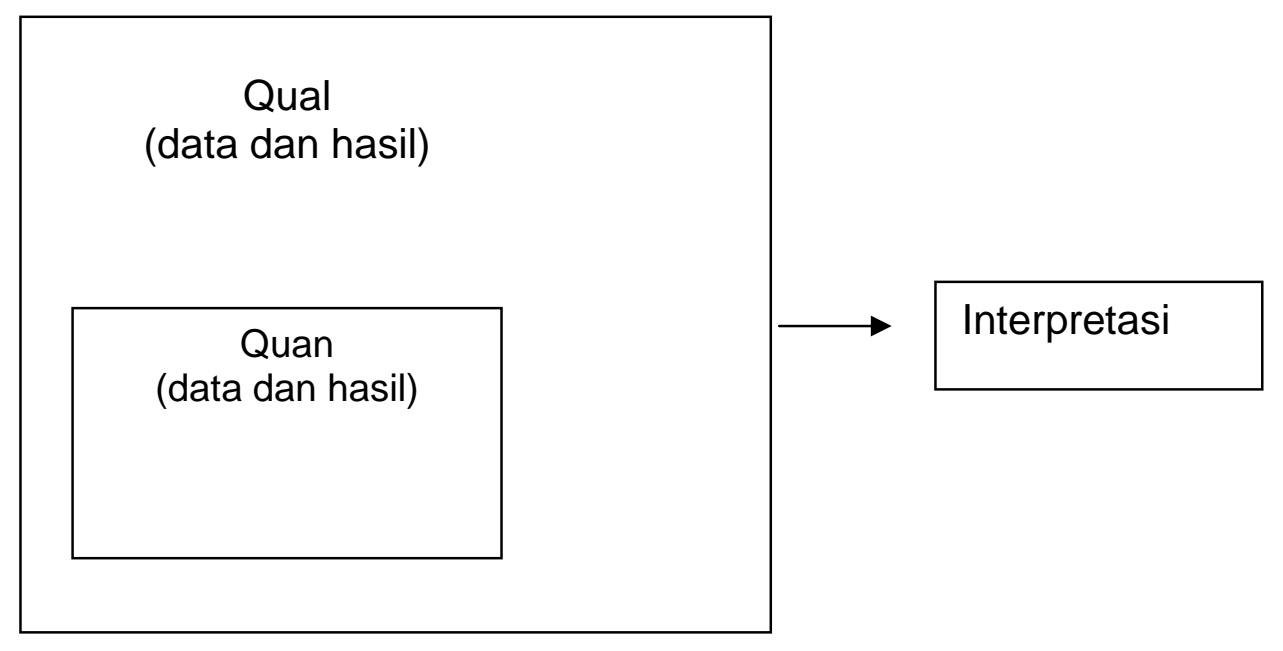

Gambar 1. Desain metode embedded mixed

Subjek dari penelitian ini adalah 50 peserta didik tingkat SMP tahun ajaran 2012/2013 di pulau Barrang Lompo. Instrumen penelitian terdiri atas: (1) Tes kemampuan berpikir kritis, dan (2) soal jawab pelajaran fisika. Data kemampuan berpikir kritis dikumpulkan menggunakan tes kemampuan 
berpikir kritis dan soal jawab. Teknik analsis data adalah analisis deskriptif dan inferensial.

\section{HASIL DAN PEMBAHASAN}

\section{Hasil}

\section{Analsisis Deskriptif}

Analsisis deskriptif menunjukkan bahwa tinggi rendahnya skor dari 50 peserta didik untuk melihat tingkat kejujuran mereka berkisar $0-2$, dengan rata-rata skor yang diperoleh 0,58 , standar deviasi 0,70 dan varians 0,49 . Hasil ini mengindikasikan bahwa perilaku karakter kejujuran peserta didik SMP masih rendah. Karakter kejujuran terhadap alam dapat berkembang dengan mempertimbangkan peserta didik di pulau Barrang Lompo.

Penemuan ini diikuti oleh pelatihan karakter kejujuran peserta didik dan proses pembelajaran, terkhusus pada aktivitas laboratorium sains. Peserta diidk dilatih untuk menghasilkan kejujuran eksperimen secara tertulis dan lisan. Jika pendidik melatih karakter pada setiap aktivitas pembelajaran dalam kelas yang diharapkan menumbuhkan kesadaran dan kejujuran peserta didik ke depannya, dan akhirnya akan diterapkan dalam kehidupan masyarakat selanjutnya.

Pada aspek yang hendak diketahui dalam menentukan tinggi dan rendahnya skor berkisar 0 dan 3, skor rata-rata adalah 0,98 dengan standar deviasi 1,17 dan varians 1,4. Hasil ini mengindifikasikan karakter keingintahuan peserta didik tingkat SMP berada dalam ketegori sedang. Karakter keingintahuan berkembang seluruhnya kepada peserta didik dengan baik.

Penemuan ini akan mengetahui makna pelatihan peserta didik dalam melaksanakan kegiatan aktivitas dan pemecahan masalah ilmu pengetahuan dalam proses pembelajaran dalam kelas sehingga peserta didik dapat melatih keingintahuan secara berkelanjutan. Pendidik dapat memberi fenomena alam yang berlawanan intuisi pengetahuan peserta didik. Permasalahan dalam merangsang pemikiran peserta didik mengenai bagaimana penyelesaian masalah. Peserta didik akan berusaha untuk mengetahui jawaban dari permasalahan yang akan diselesaikan dan meniru fisikawan.

Dalam aspek kemampuan berpikir kritis menemukan bahwa tinggi dan rendahnya setiap skor berkisar 0 dan 7 , dengan rata-rata 2,9, standar deviasi 1,91 dan varians 3,68. Hasil ini mengindikasikan karakter kemampuan berpikir kritis peserta didik SMP di pulau barrang lompo dalam kategori rendah. Kemampuan berpikir kritis berkembang secara meluas pada seluruh peserta didik di pulau barrang lompo.

Penemuan ini akan mengetahui makna pelatihan peserta didik dengan kemampuan berpikir kritis dalam aktivitas saintifik dan pemecahan masalah menggabungkan masalah alam dalam proses pembelajaran di kelas, dan karena itu kemampuan berpikir kritis dapat diterapkan secara berkelanjutan. Pendidik memberikan peserta didik kesempatan untuk memberikan pertanyaan, analisis fenomena alam dan kesimpulan eksperimen. Kemampuan berpikir kritis berhubungan dengan fenomena alam yang akan mensimulasi peserta didik untuk berpikir mengenai cara pemecahan masalah dalam pembelajaran. Peserta didik akan mencoba untuk memastikan akurasi fenomena alam melalui fakta sains dalam percobaan di laboratorium.

\section{Analisis Inferensial}

\section{a. Analisis Prasyarat}

Analisis prasyarat terdiri dari uji normalitas yang diartikan oleh plot untuk kemampuan berpikir kritis (Y) seperti yag ditunjukkan di bawah ini. 


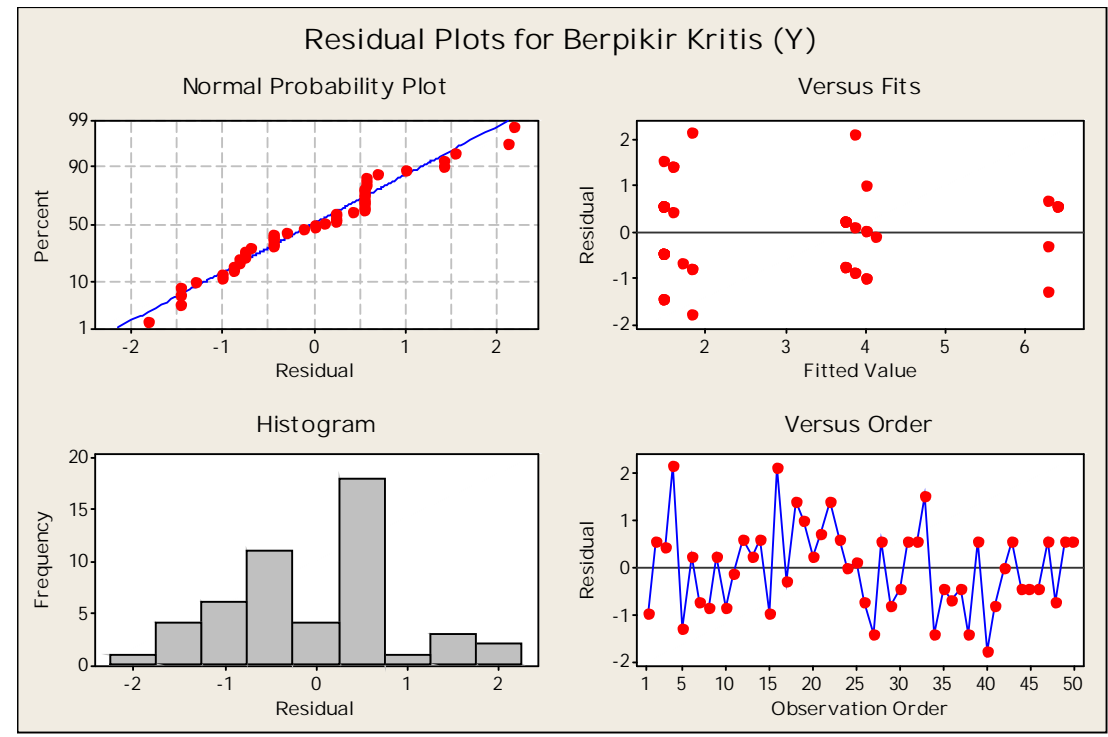

Gambar 2. Residu Plot

1) Tes Normalitas

Hasil tes normalitas ditunjukkan oleh gambar 3.

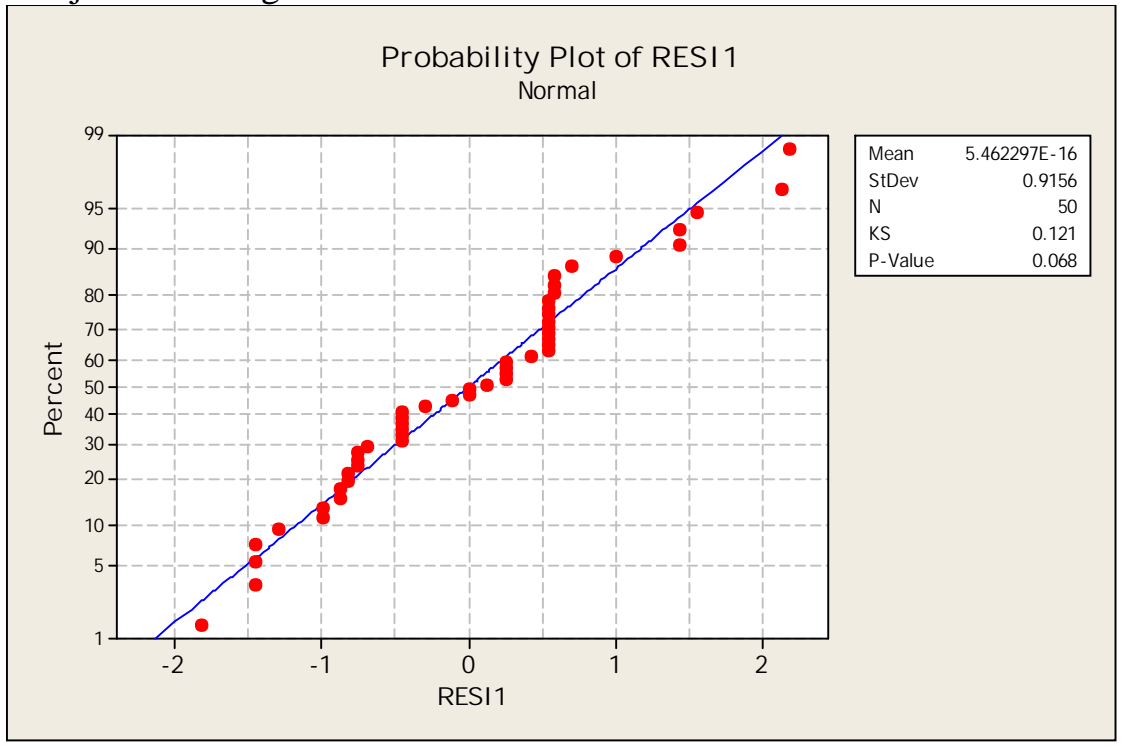

Gambar 3 Probabiliti Plot

Hasil tes homogenitas ditunjukkan pada tabel

2) Tes Homogenitas

1. Hasil dari penelitian adalah homogen dengan nilai $=1: 03$ dan $\mathrm{P}=0,427$.

Tabel.1 Hasil tes Homogenitas

\begin{tabular}{cccccc}
\hline Source & DF & SS & MS & F & P \\
Lack of Fit & 7 & 6.264 & 0.895 & 1.03 & 0.427 \\
Pure Error & 40 & 34.813 & 0.870 & - & - \\
\hline
\end{tabular}


b. Analsisis Regresi

Tabel 2 Analsis Regresi

\begin{tabular}{lccccc}
\hline \multicolumn{1}{c}{ Predictor } & Coef & SE Coef & T & P & VIF \\
\hline Constant & 1.446 & 0.1854 & 7.80 & 0.000 & \\
Honesty (X1) & 2.301 & 0.2143 & 10.74 & 0.000 & 1.271 \\
curiosity (X2) & 0.122 & 0.1288 & 0.94 & 0.350 & 1.271 \\
\hline
\end{tabular}

c. Analisis Varians

Analisis varians ditunjukkan dalam tabel 3 . Nilai regresi pada $\mathrm{F}=79.76$ dengan $\mathrm{P}=$ 0.000

Tabel 3. Analisis Varians

\begin{tabular}{lccccc}
\hline \multicolumn{1}{c}{ Source } & DF & SS & MS & F & P \\
\hline Regression & 2 & 139.423 & 69.712 & 79.76 & 0.000 \\
Residual Error & 47 & 41.077 & 0.874 & & \\
Lack of Fit & 7 & 6.264 & 0.895 & 1.03 & 0.427 \\
Pure Error & 40 & 34.813 & 0.670 & & \\
Total & 49 & 180.500 & & & \\
\hline
\end{tabular}

Durbin - Watson Statistik $=2.08735$

d. Analisis Korelasi

kemampuan berpikir kritis bergantung variabel (Y) dalam tabel 4. kritis (Y) terhadap kejujuran (X1), keingintahuan (X2) ditabulasikan dalam tabel 2.

Analisis korelasi kejujuran tidak bergantung

variabel (X1), keingintahuan (X2) dan

Tabel 4. Korelasi

\begin{tabular}{|c|c|c|c|c|}
\hline & & Honesty (X1) & Curiosity (X2) & $\begin{array}{c}\text { Critical thinking } \\
\text { (Y) }\end{array}$ \\
\hline \multirow[t]{3}{*}{ Honesty (X1) } & $\begin{array}{l}\text { Pearson correlation } \\
\text { sig (2- tailed) }\end{array}$ & 1 & $\begin{array}{l}.462^{* *} \\
.001\end{array}$ & $\begin{array}{l}.876^{* *} \\
.000\end{array}$ \\
\hline & & 24.180 & 18.580 & 57.900 \\
\hline & $\begin{array}{l}\text { covariance } \\
\mathrm{N}\end{array}$ & 0.493 & .379 & 1.182 \\
\hline \multirow[t]{5}{*}{ Curiosity (X2) } & Pearson correlation & $.462^{* *}$ & 1 & $.463^{* *}$ \\
\hline & sig (2- tailed) & .001 & & .001 \\
\hline & $\begin{array}{l}\text { sum of squares and } \\
\text { coss- products }\end{array}$ & 18.580 & 66.980 & 50.900 \\
\hline & covariance & .379 & 1.367 & 1.039 \\
\hline & $\mathrm{N}$ & 50 & 50 & 50 \\
\hline \multirow[t]{5}{*}{ Critical thinking (Y) } & Pearson correlation & $.876^{* *}$ & $.463^{* *}$ & 1 \\
\hline & sig (2- tailed) & .000 & .001 & \\
\hline & $\begin{array}{l}\text { sum of squares and } \\
\text { coss- products }\end{array}$ & 57.900 & 50.900 & 180.500 \\
\hline & covariance & 1.182 & 1.039 & 3.684 \\
\hline & $\mathrm{N}$ & 50 & 50 & 50 \\
\hline
\end{tabular}

Korelasi signifikan pada 0.01 level (2-tailed) 


\section{Pembahasan}

Hasil tes inferensial menunjukkan bahwa terdapat hubungan yang signifikan $0: 01$ level (2-tailed) antara variabel bebas kejujuran (X1), keingintahuan (X2) terhadap kemampuan berpikir kritis. Kemampuan berpikir kritis peserta didik dapat dibandingkan oleh kejujuran terhadap alam yang mencapai $76,3 \%$ dan 73,49 $\%$ untuk keingintahuan. Hal ini mengindikasikan bahwa dalam menumbuhkan kemampuan berpikir kritis pada peserta didik SMP dalam proses pembelajaran, umumnya pelatihan dalam pembelajaran yang menekankan kejujuran dan keingintahuan dalam aktivitas sains seperti di laboratorium. Hal ini sesuai dengan teori pembelajaran inkuiri dan discoveri (Sagala, 2003) dan didukung oleh hasil penelitia Sussiana et.al, (2011). Hasil penelitian terdahulu menyatakan bahwa melalui pendekatan inkuiri, kemampuan berpikir kritis peserta didik di Sekolah Dasar dapat ditingkatkan dengan hasil uji N - Gain sebesar 12.44. Subiyanto (2009) menemukan bahwa penggunaan sistem pembelajaran dengan simulasi inkuiri dapat menumbuhkan kemampuan berpikir kritis pada peserta didik SMA, dengan tertinggi indikator mengamati dan membuat asumsi, dan indikator terendah adalah aplikasi.

\section{SIMPULAN DAN SARAN}

Kesimpulan yang dapat ditarik dari penelitian ini adalah (1) perilaku karakter dan kemampuan berpikir kritis peserta didik Fisika SMP di pulau Barrang Lompo masih rendah; (2) terdapat hubungan yang signifikan antara perilaku karakter peserta didik terhadap kemampuan berpikir kritis dalam pembelajaran fisika.

\section{DAFTAR RUJUKAN}

Adi, Kuntoro C., dkk.(2010).Model Pendidikan Karakter di Universitas Sanata Dharma, Yogyakarta: Universitas Sanata Dharma.

Adler, Mortimor J. (2009).Program Paedia: Silabus Pendidikan Humanistik, Jakarta: PT, Indonesia Publishing

Asamani, Ma'mur, Jamal. (2011). Buku Panduan Internalisasi Pendidikan Karakter di Sekolah, Yogyakarta: Diva Press

Carin, A., \& Sun,R.B. (1995). Teching Scinece Through Discovery. Columbus. Charles,E.
Merril Publishing company. Abell \& Howell Company.

Creswell. J. W \& Plano Clark,V.L. (2007). Designing and Conducting. Mixed Methods Research.London \& New Delhi: Sage Publications.

Dahar, Wilis, Ratna (1993). Dasar-dasar Filosofis Pendidikan Sains, Jurnal Pengajaran MIPA, No.1-93, hlm. 27 - 30.

Darmodjo, Hendro(1986). Filsafat Ilmu Pengetahuan Alam, Jakarta: Karunika

Fisher, Alec. 2009. Berpikir kritis. Jakarta: Erlangga

Frye, Mike, et.al. (2002).Character Education: Informational Handbook \& Guide for Support and Implementation of the Student Citizen Act of 2001, North Carolina: State Board of Education, Department of Public Instruction, Division of Instructional Service

Koes, Supriyono (2003). Strategi Pembelajaran Fisika, JICA-IMSTEP, Malang: Universitas Negeri Malang

Lawson, A.E. (1979). 1980 AETS Yearbook The Psychology of Teaching for Thinking and Creativity. Clearing house for Science, Mathematics, and Environmental Education : The Ohio State University College of Education.

Poedjiadi, Anna (1987). Sejarah dan Filsafat Sains, Bandung: Yayasan Cenrawasih

Sagala, S. (2003).Konsep dan Makna Pembelajaran.Bandung: Alfabeta

Susianna, N; Parsono, M.T. (2011).Upaya Meningkatkan Keterampilan Berpikir Kritis Siswa Pada Pembelajaran Sains dengan Menggunakan metode Inqury. Proceding Seminar Nasional.Semarang, 16 April 2011.

Subiyanto. (2009). Pembelajaran Sistem Eksresi dengan CBI Simulasi Inkuiri untuk Meningkatkan Penguasaan Konsep, Keterampilan Generik dan Keterampilan Berpikir Kritis Siswa SMA.Tesis SPS UPI Bandung: Tidak Diterbitkan.

Zubaedi, 2011, Disain Pendidikan Karakter: Konsepsi dan Aplikasinya dalam Lembaga Pendidikan, Jakarta: Kencana Prenanda Media Group 